\title{
Tectonic sequence diagrams and the constraints they offer for the structural and metamorphic history of the Kullu Valley, NW India
}

\author{
L White ${ }^{1 *}$, G Lister ${ }^{1}$, M Forster ${ }^{1}$ and T Ahmad ${ }^{2}$ \\ 1 Research School of Earth Sciences, The Australian National University, Canberra, AUSTRALIA \\ 2 Department of Geology, University of Delhi, Delhi, INDIA \\ * For correspondence, email: lloyd.white@anu.edu.au
}

Recent fieldwork between the Rohtang Pass and the town of Kullu in Himachal Pradesh, India was conducted to gain an understanding of the tectonic and metamorphic history of the region. Particular attention was paid to structural cross-cutting relationships, mineral growth and evidence of metamorphic overprinting to produce tectonic sequence diagrams (Forster and Lister 2008). The aim was to evaluate three competing hypotheses as to the tectonic evolution of this part of the Himalaya: a) the undeformed ramp and flat thrust sheet model advocated by Webb et al. (2007), b) the Alpine nappe model advocated by Epard et al. (1995) and c) the imbricated thrust stack hypothesis, as suggested by Ahmad et al. (2000). These models differ widely in their consideration of factors as fundamental as the location of the actual MCT (with up to $200 \mathrm{~km}$ difference in location) or as to the nature and significance of the deformation associated with Himalayan orogenesis.

Our data suggest that the model advocated by Webb et al. (2007) does not apply. Their fold of the South Tibetan Detachment amounts to a forced correlation, and thus an imposed geometry based on the following assumptions: (1) that the rock units of the Kullu Valley are part of the Tethyan Himalaya and not the Jutogh Group (Lesser Himalayan Sequence) (e.g. Valdiya 1980); (2) the Vaikrita or Jutogh thrust is the MCT; and (3) shear zones reactivate with the different senses of movement during different tectonic events or periods of time, based on locally determined sense-of-shear criteria.

In contrast, the model advocated by Epard et al. (1995) more faithfully reflects observations that can be made in the field. The Phojal recumbent antiform is not a late stage incidental structure as proposed by Webb et al. (2007) but in fact formed subsequent to the first major foliation, and folded Barrovian isograds. This is a nappe-like structure, especially if we include a basal thrust, in the position as inferred by Thakur (1992)
The major difference in the Webb et al. (2007) and Epard et al. (1995) interpretations lies in the location of the MCT. This is located on the basis of Barrovian assemblages and the definition of lithotectonic units (i.e. Lesser Himalayan Sequence $v s$. Tethyan Himalayan Sequence). We follow the interpretation of Thakur (1992) and place the MCT equivalent at the foot of the Rohtang Pass, coincident with the Vaikrita Thrust.

The tectonic sequence diagrams suggest that early Barrovian facies metamorphism led to mineral growth that overprinted an intense fabric that was subsequently at least twice recumbently folded. These folds were themselves overprinted by intense shear zone related fabrics during Himalayan orogenesis.

\section{References}

Ahmad T, N Harris, M Bickle, H Chapman, J Bunbury and C Prince. 2000. Isotopic constraints on the structural relationships between the Lesser Himalayan Series and the High Himalayan Crystalline Series, Garhwal Himalaya. Geological Society of America Bulletin 112: 467-477

Epard JL, A Steck, JC Vannay and J Hunziker. 1995. Tertiary Himalayan structures and metamorphism in the Kulu Valley (Mandi-Khoksar transect of the Western Himalaya) - Shikar Beh Nappe and Crystalline Nappe. Schweizerische Mineralogische und Petrographische Mitteilungen 75: 59-84

Forster MA and GS Lister. 2008. Tectonic sequence diagrams and the structural evolution of schists and gneisses in multiply deformed terranes. Journal of the Geological Society, London 165: 1-17

Thakur VC. 1992. Geology of the Western Himalaya. Pergamon Press, Oxford, 366p. Valdiya KS. 1980. The two intracrustal boundary thrusts of the Himalaya. Tectonophysics 66: 323-348

Webb AAG, A Yin, TM Harrison, J Célérier and W P Burgess. 2007. The leading edge of the Greater Himalayan Crystalline complex revealed in the NW Indian Himalaya: Implications for the evolution of the Himalayan orogen. Geology 35: 955-958 